\title{
Identification Of The Secondary Metabolite Compounds From Cempedak Tree Leaves (Artocarpus Integer)
}

\author{
Ali Rakhman Hakim ${ }^{1}$ \\ ${ }^{1}$ Department of Pharmacy, STIKES Sari Mulia Banjarmasin Indonesia \\ alirakhmanhakim@gmail.com
}

\begin{abstract}
Objective: This study aims to identify the secondary metabolite compounds in Cempedak Tree Leaves (Artocarpus integer).

Methode: Cempedak tree leaves are extracted using maceration method with chloroform solvent. Identification of secondary metabolite compounds using identification methods for flavonoid compounds, alkaloids, glycosides, tannins, terpenoids, and steroids.

Results: The result for identified of secondary metabolite compounds on chloroform extract cempedak tree leaves were positively result for alkaloids and negative results for flavonoids, glycosides, tannins, terpenoids, and steroids.
\end{abstract}

Conclusion: Chloroform extract of cempedak tree leaves only identified alkaloids

Keywords: Alkaloids, Artocarpus integer, cempedak tree leaves, secondary metabolite. 


\section{INTRODUCTION}

Plants can produce several drugs or chemical compounds that can be used for treatment, but with great advances in the chemical synthesis of drugs in the past few years have caused synthetic drugs have increased dramatically [1]. Utilization of plants as a medicine still plays an important role in drug development efforts and disease prevention efforts, although modern medicine or synthesis more and more [2].

Cempedak plant is a plant that can flourish in the yard of the house. Currently very little research on cempedak plants. One part of cempedak plants that can be studied is the leaves. Cempedak trees have leafy leaves. The leaf part has some potential for alternative treatments such as antioxidants and antibacterials [3].

\section{RESEARCH METHODE}

The tools used in this research are analytical scales, maceration tools, water bath, beaker, a reaction tube, dropper pipette, filter paper, and stirring rod. The materials used in this study were a cempedak leaf, chloroform, concentrated $\mathrm{HCl}, \mathrm{FeCl} 3$, glacial acetic acid, anhydrous acetic acid, dragendorff reagent, Mayer, Liebermann Burchard, Falkowski, and magnesium powder.

Leaf Artocarpus integer cleaned with running water, then cut into small pieces and dried in the open place not exposed to direct sunlight.

\section{Creating Extracts}

The extraction is done by maceration. Simplicia leaf Artocarpus integer soaked with chloroform solvent for 3 days [4].

\section{Chemical identification}

Chemical identification using extract and reaction test. Reaction tests for alkaloids, flavonoids, steroids, terpenoids, tannins, and glycosides.

\section{RESULTS}

The results obtained from the test can be seen in Table 1.

Table 1. Identification of Artocarpus integer extract chemistry

\begin{tabular}{cc}
\hline $\begin{array}{c}\text { Chemistry } \\
\text { compounds }\end{array}$ & Results \\
\hline Alkaloid & + \\
\hline Flavonoid & - \\
\hline Tannin & - \\
\hline Glikosida & - \\
\hline Steroid & - \\
\hline Terpenoid & - \\
\hline
\end{tabular}

\section{DISCUSSION}

Leaves Artocarpus integer dried aims to maintain the stability of chemical compounds contained in the simplicia [5]. In this research the extraction process using maceration method. The maceration method is considered good enough in the effort to obtain the rendement of the extract $[6,7,8]$.

Chemical identification tests are performed for the identification of chemical compounds of alkaloids, flavonoids, steroids, terpenoids, tannins, and glycosides. Leaf 
chloroform extract of Artocarpus integer found positive results for alkaloid compounds and negative results for steroids, alkaloids, tannins, terpenoids, and glycosides.

The alkaloids have a lot of potential as a medicine. Alkaloids can be used as antituberculosis [9], antitumor [10], antipyretic [11], antimicrobial, antimalarial, cytotoxic, and anti-HIV [12].

\section{CONCLUSION}

Leaf chloroform extract of Artocarpus integer only positively contains alkaloids.

\section{REFERENCE}

[1] Heinrich M, Barnes J, Gibbons S, Williamson EM. Fundamentals of Pharmacognosy and Phytotherapy $2^{\text {nd }}$ Edition. Elsevier. 2012.

[2] Shah B, Seth AK. Textbook of Pharmacognosy and Phytochemistry. India: Elsevier, 2010.

[3] Sultana B, Anwar F, Ashraf M. Effect of Extraction Solvent/Technique on the Antioxidant Activity of Selected Medicinal Plant Extracts. Molecules, 14(6), pp. 2167-2180, 2009.

[4] Sutomo, Agustina N, Arnida, Fadilaturrahmah. Studi Farmakognostik dan Uji Parameter Nonspesifik Ekstrak Methanol Kulit Batang Kasturi (Mangifera Kasturi Kosterm.). J Pharmascience Vol.04, 01, pp. 94-101, 2017.

[5] Winangsih, Prihastanti E, Parman S. Pengaruh Metode Pengeringan Terhadap Kualitas Simplisia Lempuyang Wangi (Zingiber aromaticum L). Bulletin Anatomi dan Fisiologi Vol.XXI No.01, 2013.

[6] Trusheva B, Trunkova D, Bankova V. Different Extraction Methods Of Biologically Active Components From Propolis: A Preliminary Study. Chemistry Central Journal.
;1:13. doi:10.1186/1752-153X-1-13. 2007.

[7] Ewansiha JU, Garba SA, Mawak JD, Oyewole OA. Antimicrobial Activity of Cymbopogon Citratus (Lemon Grass) and It's Phytochemical Properties. Frontiers in Science, 2(6): pp. 214-220, 2012.

[8] Azmir J, Zaidul ISM, Rahman MM, Sharif KM, Mohamed A, Schena F, Jahurul MHA, Ghafoor K, Norulaini NAN, Omar AKM. Techniques for extraction of bioactive compounds from plant materials: A review. Journal of Food Engineering, 117, pp. 426 - 436. 2013.

[9] Kishore N, Mishra BB, Tripathi V,

Tiwari VK. Alkaloids as Potential Anti-Tubercular Agents. Fitoterapia 80, pp. 149-163, 2009.

[10] Gao W, Bussom S, Grill SP, Gullen EA, Hu YC, Huang $\mathrm{X}$, Zhong $\mathrm{S}$, Kaczmarek C, Gutierrez J, Francis S, Baker DC. Structure-Activity Studies Of Phenanthroindolizidine Alkaloids As Potential Antitumor Agents. Bioorganic \& Medicinal Chemistry Letters, Vol. 17, Issue 15, pp. 43384342. 2007.

[11] Ahmad I, Khan H, Gilani AU, Kamal MA. Potential of Plant Alkaloids as Antipyretic Drugs of Future. Curr Drug Metab, 18(2): pp. 138-144, 2017.

[12] Iwasa K, Moriyasu M, Tachibana Y, Kim HS, Wataya Y, Wiegrebe W, Bastow KF, Cosentino LM, Kozuka M, Lee KH. Simple Isoquinoline and Benzylisoquinoline Alkaloids as Potential Antimicrobial, Antimalarial, Cytotoxic, and Anti-HIV Agents. Bioorganic \& Medicinal Chemistry, Vol. 9, Issue 11, pp. 2871-2884, 2001. 